ISSN: 2586-6036 @ 2019 JWMAP. http://www. welfareconvergence.or.kr doi: http://dx.doi.org/10.13106/jwmap.2019.Vol2.no2.1.

\title{
Female Director and Tax Aggressiveness of Listed Insurance Firms: Insights from Nigeria
}

\author{
Sunday Oseiweh OGBEIDE ${ }^{1}$, Austine ODILU ${ }^{2}$ \\ 1. First Author \& Corresponding Author $\mathrm{PhD}$, Department of Accounting and Finance, Faculty of Social and \\ Management Sciences, Elizade University, Ilara- Mokin, Ondo State, Nigeria. GSM: +234-8132490958. \\ Email: Sunday.ogbeide@elizadeuniversity.edu.ng \\ 2. Co-Author Department of Business Education, College of Education, Ekiadolor, Benin City, \\ Edo State, Nigeria.
}

Received: May 23, 2019. Revised: June 01, 2019. Accepted: June 07, 2019.

\begin{abstract}
This study empirically examined the effect of female director on tax aggressiveness of listed insurance firms in Nigeria. The main objective of this research was to empirically investigate the effect of female board members on tax aggressiveness, determine the composition and representation of female directors on the board of insurance companies, find out how tax aggressive are listed insurance firms and apply the BLAU (1977) index method to measure female director representation as a departure from conventional approaches specifically in the Nigerian context in the reference period, 2014 to 2018. The population of the study consists of all the quoted insurance firms as at 31st December, 2016. A sample of twenty eight (28) quoted insurance firms was selected and data were collected over the period. Inferential statistic consisting of the General Method of Moment was used for the data analysis. The results obtained reveal that board size is negative and exerts significant impact on tax aggressiveness in insurance firms in Nigeria. The study therefore recommends that the Federal government has to come up with a policy to respond to the marginalization of female on the insurance firm corporate board in Nigeria. The aim of this policy thrust should be targeted at reducing politics and biasness against women on the corporate boards of listed insurance firms.
\end{abstract}

Keywords: Tax Aggressiveness, BLAU Index, Board Size, Female Director, Firm Size.

JEL Classifications: F38, G22

\section{Introduction}

Female directors over time appear to be over marginalized and grossly under represented on the board of listed firms particularly in the insurance sector in developing countries like Nigeria. This is despite the fact majority of them are attentive to details in their duties, have the educational qualifications, professional trainings and stable emotional status (Ogbeide, 2018). There are some women who have been endowed with managerial skills, experiences and political clouts to engender uncommon significant positive influence on firms, yet they are not permitted to show case such perhaps due to policy biasness (Ogbeide, 2018). Some countries of the world like France, Belgium, Germany and others have since begun through legislation, the inclusion of a certain quota of female member on the board of companies. This is to promote equality advocacy and to ensure the promotion of gender friendliness which ultimate goal has spiral positive effects such as reduction of significant cost like tax expenses. Minimization of tax expenses is otherwise refers to as tax aggressiveness and it has dual effects to a firm irrespective of the sector. It increases net earnings, wealth of the shareholders on one hand and reduces revenue accruable to the government through taxation. Taken this into consideration, cautions are exercised by the directors to avoid the adverse effect of 
tax evasion. What the directors do in this regard is to take advantages of the loopholes in existing tax laws in the jurisdiction to effectively carry out tax aggressiveness. However, tax aggressive activities do vary from firms to the other particularly by way of size and industry differential. A larger firm for instance may drive tax aggressiveness perhaps because of its investment in assets which assist it to take advantage of loan facilities in banks. Larger firms may enjoy allowable items like capital allowance and tax shield arising from the use of fixed assets to reduce tax liability. Intuitively, insurance firms irrespective of size naturally ought to be tax aggressive so as to maximize earnings given the numerous claims they need to settle to policies holders. The occurrence of this through the instrumentality of female directors in the insurance sector of Nigeria lacks empirical evidences; hence this research. Similarly, a glance at the yearly annual reports of companies including insurance companies in Nigeria does reveal very few or no female board directors in the segment of directors' report. Where they do sometime have, it is either one or at most three out of a large board size. For instance, there is very scanty or zero proportion in the composition of the non- executive director of quoted insurance companies in the Nigerian context. There is no doubt exclusion of the female counterparts in the non- executive director composition in the corporate board may stunt the expected oversight function, have adverse effect in the strategic management of the insurance company, including tax liability reduction. Furthermore, the different committees that assist in the attainment of strategic goals in a firm hardly have female as the head in developing countries like Nigeria; even in the audit committee, risk management committee and other sub committees in the Nigerian quoted insurance companies, hardly do female board members feature prominently in terms of occupying notable position (Ogbeide, 2018). This observable gap is what this study seeks to address by examining the influence of female directors on tax liability minimization and adequacy of their representation on the board of listed insurance companies in the Nigerian context with a view to contributing to literature on tax aggressiveness globally.

Prior researches by Oyeleke, Erin and Emeni (2016), Boussaidi and Hamed (2015), Aliani and Zarai (2012) showed that size of female directors has always been empirically measured as the relationship between numbers of women on the corporate board to the aggregate board number of directors on the board. There has been less reliance on the use of BLAU (1977) index method in a heterogeneous board particularly in the context of Nigeria. This conventional measurement to be specific is imbued with measurement error and empirical weakness (BLAU, 1977). This constitutes a gap which this study seeks to bridge by applying the index method. Several researchers have over relied on the use of panel least square to analyze researches relating to tax aggressiveness despite its short coming such as endogeneity. Endogeneity problems in panel researches include omitted variables, measurement errors and simultaneity in the context of tax management (Hairul, Ibrahim, \& Siti, 2014). Since tax management also concerns tax aggressiveness, the essence of using the dynamic panel data regression method rather than the panel least square cannot be overemphasized. In the view of Hairul et al. (2014), strategies for tax aggressive of company do transcend to the following year, and the possibility of this transcendental effect gets increased especially under self-assessment system. This stems from the fact that quoted firms do estimate their tax liabilities and submit same to the relevant tax authorities. The firms are also permitted to revise these estimates during the assessment period; thus making the firm tax planning activities continuous on a yearly basis. This creates the probability of prior year's tax aggressiveness strategies to extend to the current year (Hairul et al., 2014). It is this transcendental effect that the dynamic panel method of estimation accounts for in tax management which over time has been largely neglected in researches. Section two is literature review, section three is methodology, and section four is empirical analysis and reporting while section five concentrated on conclusion and recommendations.

\section{Literature Review}

\subsection{Theoretical framework}

This study relies on the women risk aversion theory to explain the association between female director and tax aggressiveness. Women risk aversion theory portends that women tend to be more risk averse when assessing opportunities with less risk, minimizing costs such as tax costs in the context of tax aggressiveness. They research more thoroughly, including probing how the business can extricate itself if tax aggressive behaviour/action or any 
other decisions failure occurs. In the context of female directorship and tax aggressiveness, the postulation is that women have the tendency to measure risk, examine the possibilities and to take the time to calculate potential costs and benefits before taking decisions on tax in firms. The very origin and proponent of the women risk aversion theory is not explicit in economics and finance literature. It can however said to be deduced from the pioneering work of Bernoulli (1954) on gambling and the St. Petersburg paradox in the 17th century which was devoted to understanding human decision making under uncertainty as well as the expected utility theory of Kahneman and Tversky (1979). The expected utility theory aptly explains decision making by economic agents under risk. The economic agent like a manager weighs the gain over the loss in decision and then takes a position in that regard. Risk aversion as a concept in economics and finance explain how people behave when they are expose to uncertain outcomes. Risk averse is defined as the propensity to prefer an offer with an expected lower but more certain outcome, compared to an offer with a higher expected outcome with more risk (Binay \&Virginia 2008). Naturally, managers in organizations appear to show divergent risk aversion attitudes in decision-making. In this context, women may be seen as more risk averse because they are very rational in decision making unlike the male counter parts who are sometimes risk lovers. Women are very cautious of the negative implications of costs, including tax cost in the performance of firms. They could be cautious in minimizing tax cost due to certain adverse effects like shutting down a company permanently, reputational cost, fines and penalties.

\subsection{Empirical Review}

As part of measure to ameliorate the scantiness or non-existent of female directors on corporate board, Kramer, Konrad and Erkut (2006), Lakhal, Aguir, Lakhal and Malek (2015) suggest that at least, a pool of three female directors is seen to be able to influence corporate outcomes to constitute a "critical mass. In the context of literature on gender differences in risk behaviour and tax compliance, Croson and Gneezy (2009) and Hasseldine (1999) surmise that women do have higher levels of tax compliance while men do show lower level of tax compliance. In the case of significant differences between the sexes, Lewis, Carrera, Culls and Jones (2009) opined that women were often judged more suitable than men. This theoretical assertion has however not be empirically tested in the context of corporate governance mechanisms and tax aggressiveness in Nigeria listed firms. Over the years, there have been increased clamor for gender diversity which have continued to result in greater female participation on the corporate board of directors across developed and developing countries. This is due to their perceived positive influence on the corporate and financial decisions making. In quoted firms, female directors are aspects of corporate governance mechanisms that influence the decision making process. Higher participation of women on corporate board is presumed to engender significant information and knowledge perhaps due to their divergent range of professional experience, training and individual meticulousness, and care. Lanis et al. (2015) posit that corporate board comprising of female directors are likely to promote honesty and high ethical values, greater independent reasoning, more informed decisions that increase the level of transparency at the board level and higher credibility within the board. Therefore, gender differentials, the interpretation of tax regulations and tax compliance levels may be dependent on the masculine traits, dominance, competitiveness, aggressiveness and feminine characters such as kindness, value for life and risk avoidance (Adams \& Funk, 2012).

On the empirical fronts, research in the accounting and finance literature has continued to examine the nexus between female directors and tax aggressiveness. The outcome of the myriad studies remained conflicting, mixed and inconclusive. Aliani and Zarai (2012) empirically examined demographic diversity in the board and corporate tax planning in American firms for the period 1996 to 2009. A sample of 300 firms (S \& P 500) was selected. The data were analyzed with panel least square estimation method. The result revealed that the size of female directors on the board is not significant and does not have an effect on tax aggressiveness of the firms in the period considered. Adams and Funk (2012) found that there is a negative effect between female directors and tax optimization. They concluded that the presence of women does not enhance the tax planning strategy within the firm but leads to a further decrease in effective tax rates. Zemzem and Flouhi (2013) through empirical investigation established that the percentage of female directors influences the tax aggressiveness activities on a sample of SBF 120 index French companies amongst other corporate governance mechanism variables in America. Lanis et al. (2013) empirical study indicates that a negative and significant relationship exists between female directors and tax aggressiveness of the sample firms in Greece using the panel least square method. Thus, when a number of women are adequately represented on the corporate board, there is the tendency that monitoring and oversight function may improve which could results to reduction in tax liability and ultimately engender tax aggressiveness. Oyeleke et al. (2016) empirically examine the relationship between the board of directors' gender diversity and tax aggressiveness of banks listed on the Nigerian Stock Exchange for the period 2012 to 2014 on a sample of 11 banks. The study employed a panel regression analysis. The finding revealed that higher proportion of female directors significantly 
reduced the possibility of tax aggressiveness. Similarly, female directors on the bank boards were observed to be positively correlated to effective tax rate, implying that higher ratio of women as directors naturally should lead to lower tax aggressiveness as effective tax rate (ETR) increases. The reason adduced by the researchers is that the percentage of women sitting on corporate board is quite negligible in comparison to the men counterpart. This finding corroborates the view of Aliani and Zarai (2012) that the inadequacy of female directors stems from the under representation and insufficiency of professional women in senior and key management positions. This development may boil down to the reason for women directors to be insignificant in minimizing tax liability. The percentage of female sitting on board may be insignificant to engender enough influence on the corporate board tax policies.

\section{Method}

This study uses the longitudinal research and causal effect research designs. The population of the study is the entire listed companies in the insurance companies in Nigeria. The sample size of the study is twenty eight listed insurance firms. The sample size was selected using the simple random sampling technique. Data were sourced from the secondary source, basically from the annual financial statements of the listed insurance companies in the under the reference period.

\subsection{Model Specification and Method of Data Analysis}

The models used in this study adapt to the framework of Oyeleke et al(2016). The models principally relate to female directors and tax aggressiveness in the Nigerian banking sector. The mathematical and stochastic form of the models is stated algorithm as follows:

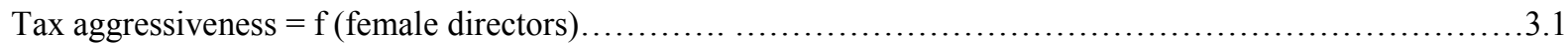

This is stated in econometric form as:

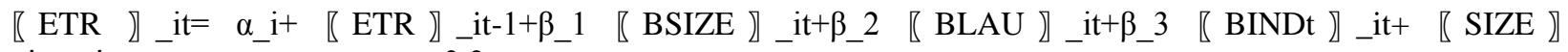
it $+\varepsilon_{-}$it.....................................

$\beta \_1-\beta \_5$ are parameters of estimation. The subscripts $i$ and $t$ refer to individual firms and time period (2012-2016) respectively. ETR represents tax aggressiveness of the sampled firms., Y, $\beta \_1$ to $\beta \_5$ are slopes to be estimated and $\varepsilon$ is the error term. The coefficient of lagged dependent variable; $\mathrm{Y}$ is expected to be positive. The inclusion of the lagged dependent variable [ETR】_it-1 is meant to take care of potential endogeneity of the independent variables which included likelihood of omitted variables, simultaneity and variable measurement error in the context of dynamic panel data analysis through the General Method of Moment (GMM). This study relies on the women risk aversion theory to explain the association between female director and tax

\subsection{Variables Description}

$\mathrm{ETR}=$ Effective tax rate

BSIZE $=$ Board size

$\mathrm{BLAU}=\mathrm{Blau}$ index for female director size

$\mathrm{BIND}=$ Board Independence

SIZE $=$ Firm size

$\varepsilon=$ error term

\subsection{Measurement of Variables}

Table 1: The object's character and the audience's taste and variety for the movie and restaurant's appeal

\begin{tabular}{|c|c|c|c|c|}
\hline S/N & Variables & Type of ariable & Measurement & Sources \\
\hline 1. & Tax aggressiveness & Dependent variable & Effective tax rate & $\begin{array}{c}\text { Boussaidi \& Hamed } \\
(2015)\end{array}$ \\
\hline 2. & $\begin{array}{c}\text { Effective tax rate } \\
(\text { ETR) }\end{array}$ & Dependent variable & $\begin{array}{c}\text { Total cash tax expenses divided by pre- } \\
\text { tax income, expressed in percentage. }\end{array}$ & $\begin{array}{c}\text { Boussaidi \& Hamed, } \\
\text { 2015, Oyeleke \& Emeni, } \\
2016\end{array}$ \\
\hline
\end{tabular}




\begin{tabular}{|c|c|c|c|c|}
\hline 3. & Board size & Independent variable & $\begin{array}{c}\text { Total number of directors on the corporate } \\
\text { board }\end{array}$ & $\begin{array}{c}\text { Oyeleke et al 2016, } \\
\text { Boussaidi \& Hamed }\end{array}$ \\
\hline 5. & Female Director & Independent variable & Blau index method & BLAU (1977) \\
\hline 6. & Size & Independent & $\begin{array}{c}\text { The logarithm of total assets of the } \\
\text { insurance company }\end{array}$ & $\begin{array}{c}\text { Boussaidi \& Hamed } \\
\text { (2015) }\end{array}$ \\
\hline 7. & Board independence & Independent & $\begin{array}{c}\text { Proportion of non-executive directors } \\
\text { divided by the total board of directors }\end{array}$ & Hairul et al., 2014 \\
\hline
\end{tabular}

Source: Researcher's compilation(2019)

\subsection{Empirical Analysis and Reporting}

\subsubsection{Level of Tax Aggressiveness of Listed Insurance Firms in Nigeria}

This part of the study analyzed and report how tax aggressive the sampled insurance firms are on individual basis in the financial sector of Nigeria. To examine the level of tax aggressiveness of the firms, four (4) modes of classification adapted from the study of Ogbeide (2018) is used. These include $0 \leq 10 \%$ category, $>10 \leq 20 \%$ category; $\leq 30 \%$ category and $>30 \%$ category. $>1 \leq 10 \%$ categories are those firms which are regarded as highly tax aggressive. $>10 \leq 20 \%$ groups are those companies which may be seen as moderately tax aggressive. $\leq 30 \%$ categories are firms whose tax aggressiveness level is at equilibrium with the statutory tax rate of $30 \%$. $>30 \%$ categories are companies that are not tax aggressive at all. So, the categories on the other hand may be labeled in the same order as categories A, B, C and D. This may be summarized in the table 2 below.

Table 2: Category of Insurance Firms based on Tax Aggressiveness level

\begin{tabular}{|c|c|c|c|}
\hline S/N & Categories & Percentage & Remark \\
\hline 1 & A & $0 \leq 10 \%$ & Highly tax aggressive \\
\hline 2 & B & $>10 \leq 20 \%$ & Moderately tax aggressive \\
\hline 3 & C & $\leq 30 \%$ & Tax aggressive at equilibrium with the statutory tax rate \\
\hline 4 & D & $>30 \%$ & Not tax aggressive \\
\hline
\end{tabular}

Source: Adapted from Ogbeide and Iyafekhe (2019) Study.

Firms in category A are those which maintain highly tax aggressive policy. This kind of policy tends to encourage increase in net income and increase in shareholders' wealth for a period. However, these categories of firms may suffer the implication of tax evasion and by extension manager rent extraction. These categories of firms employ tax experts and consultants with very effective tax strategies to drastically reduce the amount of tax expenses payable to the state (government). It implies the managers/board of directors have the necessary tax management/audit experience to manipulate the loopholes in the tax law to minimize tax expense payment to the government and consequently enjoy high tax income. Category B firms are firms that are deemed to maintain moderate tax aggressive policy. These categories of companies do not employ effective tax aggressive policy to drastically reduce the amount of tax expenses payable to the government. This is possible if they engage less the services of tax consultants/practitioners to control tax expense payment. These categories of firms may not suffer from the adverse effect of tax evasion as well as manager and organization reputation risks. Categories $\mathrm{C}$ firms are firms whose tax aggressive policy is at equilibrium with the statutory company income tax rate of $30 \%$. They contribute less to tax expense minimization and as such may not be enhancing shareholder wealth from tax expense management. We may regard these categories of firms as being risk averse. Category D firms are those not within the perimeter of tax aggressiveness. They are not mindful of the implication of tax expense to the revenue and the wealth of the shareholders.

Table 3: Tax Aggressiveness of Insurance Firms on Individual basis

\begin{tabular}{|c|c|c|c|c|c|c|}
\hline S/N & Company & $\begin{array}{c}\text { Average } \\
\text { ETR }\end{array}$ & $\begin{array}{c}\text { Statutory } \\
\text { Tax Ratio } \\
\text { (STR) }\end{array}$ & $\begin{array}{c}\text { Signs of } \\
\text { Direction }\end{array}$ & Report & Category \\
\hline 1. & African Alliance Insurance Plc & 0.8 & $30 \%$ & ETR $<$ STR & TA & A \\
\hline 2. & Aiico Plc & $9.35 \%$ & $30 \%$ & ETR $<$ STR & TA & A \\
\hline 3. & Axa Mansard plc & $13.82 \%$ & $30 \%$ & ETR $<$ STR & TA & B \\
\hline 4. & Consolidated Hallmark Plc & $15.41 \%$ & $30 \%$ & ETR $<$ STR & TA & B \\
\hline 5. & Continental Reinsurance Plc & $22.28 \%$ & $30 \%$ & ETR $<$ STR & TA & C \\
\hline
\end{tabular}




\begin{tabular}{|c|c|c|c|c|c|c|}
\hline 6. & Cornerstone Insurance Plc & $2.91 \%$ & $30 \%$ & ETR $<$ STR & TA & A \\
\hline 7. & Custodian and Allied Insurance Plc & $16.11 \%$ & $30 \%$ & ETR $<$ STR & TA & B \\
\hline 8. & Equity Assurance Plc & $-6.21 \%$ & $30 \%$ & ETR $>$ STR & NTA & D \\
\hline 9. & Gold Link Insurance Plc & $6.77 \%$ & $30 \%$ & ETR $<$ STR & TA & A \\
\hline 10. & Great Nig. Insurance Plc & $-13.86 \%$ & $30 \%$ & ETR $>$ STR & NTA & D \\
\hline 11. & Guinea Insurance Plc & $4.91 \%$ & $30 \%$ & ETR $<$ STR & TA & A \\
\hline 12. & International Energy Insurance Plc & $-15.73 \% *$ & $30 \%$ & ETR $>$ STR & NTA & D \\
\hline 13. & Lasaco Assurance PLC & $15.03 \%$ & $30 \%$ & ETR $<$ STR & NTA & B \\
\hline 14. & Law Union \& Rock Insurance Plc & $16.98 \%$ & $30 \%$ & ETR $<$ STR & TA & B \\
\hline 15. & Linkage Assurance Plc & $2.57 \%$ & $30 \%$ & ETR STR & TA & A \\
\hline 16. & Mutual Benefit Assurance Plc & $2.14 \%$ & $30 \%$ & ETR $<$ STR & TA & A \\
\hline 17. & Nem Insurance Plc & $13.55 \%$ & $30 \%$ & ETR $<$ STR & TA & B \\
\hline 18. & Niger Insurance Plc & $35.60 \%$ & $30 \%$ & ETR $>$ STR & NTA & D \\
\hline 19. & Prestige Assurance Plc & $237.27 \%$ & $30 \%$ & ETR $>$ STR & NTA & D \\
\hline 20. & Regency Alliance Insurance Plc & $22.77 \%$ & $30 \%$ & ETR < STR & TA & C \\
\hline 21. & Royal Exchange Plc & $20.90 \%$ & $30 \%$ & ETR $<$ STR & TA & C \\
\hline 22. & Sovereign Trust Insurance Plc & $18.99 \%$ & $30 \%$ & ETR STR & TA & B \\
\hline 23. & Staco Insurance Plc & $31.98 \%$ & $30 \%$ & ETR $>$ STR & NTA & D \\
\hline 24. & Standard Alliance Plc & $2.08 \%$ & $30 \%$ & ETR < STR & TA & A \\
\hline 25. & Unic Insurance Plc & $-0.27 \%$ & $30 \%$ & ETR >STR & NTA & D \\
\hline 26. & Unity kapital Assurance Plc & $32.61 \%$ & $30 \%$ & ETR $>$ STR & NTA & D \\
\hline 27. & Universal Plc & $2.08 \%$ & $30 \%$ & ETR < STR & TA & A \\
\hline 28. & Wapic Insurance Plc & $68.54 \%$ & $30 \%$ & ETR $>$ STR & NTA & D \\
\hline
\end{tabular}

Where: STR $=$ Statutory Tax Rate $(30 \%)$ and average ETR = Average effective tax rate. From the result presented in the table above, it can be observed that about 9 companies were in category A (highly tax aggressive) in the insurance sector in Nigeria. These insurance firms are African Alliance Insurance PLC, Aiico Insurance PLC, Cornerstone PLC, Gold Link Insurance PLC, Guinea Insurance PLC, Linkage Assurance PLC, Mutual Benefits Assurance PLC, Standard Alliance PLC and Universal Insurance PLC. Seven of the insurance firms were moderately tax aggressive. They includeSovereign Trust Insurance PLC, Nem Insurance PLC, Law union \& Rock Insurance PLC, Lasaco Assurance PLC, Custodian and Allied Insurance PLC, Consolidated Hall mark Insurance PLC and Axa mansard Insurance PLC. Three of the insurance companies were tax aggressive at equilibrium and they are Continental Reinsurance PLC, Regency Alliance Insurance PLC and Royal Exchange PLC. However, nine (9) insurance companies were not tax aggressive at all in the insurance industry in Nigeria. These Insurance companies are Wapic Insurance PLC, Unity capital Assurance PLC, Unic Insurance PLC, Staco Insurance PLC, Prestige Assurance PLC, Niger Insurance PLC, International Energy Insurance PLC, Great Nig. Insurance PLC and Equity Assurance PLC respectively.

\subsubsection{Determination of female director representation in Insurance firms in Nigeria}

The purpose of this part is to report the female director representation in the quoted insurance companies in Nigeria. This assists us to know if there is marginalization of women on the board of quoted insurance firms in the context of financial sector in Nigeria. In doing this, five (5) modes of classifications are used to determine the level of female size in each company in each industry. The modes of classifications are indicated in the table below:

Table 4: Categorization of female director representation in the sampled Insurance Firms

\begin{tabular}{|c|c|c|c|}
\hline S/N & Category & Percentage & Remark \\
\hline 1. & A & $=0 \%<1 \%$ & Not represented \\
\hline 2. & B & $\geq 1 \% \leq 10 \%$ & Fairly represented \\
\hline 3. & $\mathrm{C}$ & $>10 \% \leq 30 \%$ & Averagely represented \\
\hline 4. & $\mathrm{D}$ & $>30 \% \leq 50 \%$ & Adequately represented \\
\hline 5. & $\mathrm{E}$ & $>45 \%$ & represented \\
\hline
\end{tabular}

Source: Adapted from Ogbeide and Iyafekhe (2019) Study.

From the table 4, category $\mathrm{A}$ is for firms that have zero percentage $(0 \%)$ of female gender represented on the corporate board. B category are insurance firms that have less than or equal to ten percentage (10\%) of women 
marginally represented on the corporate board. Category C firms are those firms that have less than $30 \%$ of women on the corporate board. They are seen to have women fairly represented on the corporate board. Category D belongs to firms that have women averagely represented on the corporate board while categories $\mathrm{E}$ are firms with adequate representation of female on the corporate board. The reports of the categories of women representation on the corporate board of the listed sampled insurance firms are presented in the table below:

Table 5: Computation of Female Director Representation in Listed Insurance Firms in Nigeria

\begin{tabular}{|c|c|c|c|c|c|}
\hline $\mathbf{S} / \mathbf{N}$ & Company & $\begin{array}{c}\text { Male Director } \\
\text { Representation } \\
\text { Average }\end{array}$ & Category & $\begin{array}{c}\text { Female Director } \\
\text { Representation } \\
\text { Average }\end{array}$ & Category \\
\hline 1 & African Alliance Insurance Plc & $26(72.2 \%)$ & $\mathrm{E}$ & $10(27.8 \%)$ & $\mathrm{C}$ \\
\hline 2 & Aiico Plc & $41(93.2 \%)$ & $\mathrm{E}$ & $3(6.8 \%)$ & $\mathrm{B}$ \\
\hline 3 & Axa Mansard plc & $47(73.4 \%)$ & E & $17(26.6 \%)$ & $\mathrm{C}$ \\
\hline 4 & Consolidated Hallmark Plc & $37(82.2 \%)$ & $\mathrm{E}$ & $8(17.8 \%)$ & $\mathrm{C}$ \\
\hline 5 & Continental Reinsurance Plc & $44(88 \%)$ & $\mathrm{E}$ & $6(12 \%)$ & $\mathrm{C}$ \\
\hline 6 & Cornerstone Insurance Plc & $54(90 \%)$ & $\mathrm{E}$ & $6(10 \%)$ & $\mathrm{B}$ \\
\hline 7 & Custodian and Allied Insurance Plc & $31(96.9 \%)$ & $\mathrm{E}$ & $1(3.1 \%)$ & $\mathrm{B}$ \\
\hline 8 & Equity Assurance Plc & $38(84.4 \%)$ & $\mathrm{E}$ & $7(15.6 \%)$ & $\mathrm{C}$ \\
\hline 9 & Gold Link Insurance Plc & $32(97 \%)$ & $E$ & $1(3.0)$ & $\mathrm{B}$ \\
\hline 10 & Great Nig. Insurance Plc & $51(79.7 \%)$ & $\mathrm{E}$ & $13(20.3 \%)$ & $\mathrm{C}$ \\
\hline 11 & Guinea Insurance Plc & $41(97.6 \%)$ & $\mathrm{E}$ & $1(2.4 \%)$ & $\mathrm{B}$ \\
\hline 12 & International Energy Insurance Plc & $35(81.4 \%)$ & $\mathrm{E}$ & $8(18.6 \%)$ & $\mathrm{C}$ \\
\hline 13 & Lasaco Assurance PLC & $31(63.3 \%)$ & $\mathrm{E}$ & $18(36.7 \%)$ & $\mathrm{D}$ \\
\hline 14 & Law Union \& Rock Insurance Plc & $28(60.9 \%)$ & $\mathrm{E}$ & $18(39.1 \%)$ & $\mathrm{D}$ \\
\hline 15 & Linkage Assurance Plc & $56(94.9 \%)$ & $\mathrm{E}$ & $3(5.1 \%)$ & $\mathrm{B}$ \\
\hline 16 & Mutual Benefit Assurance Plc & $70(94.6 \%)$ & $\mathrm{E}$ & $4(5.1 \%)$ & $\mathrm{B}$ \\
\hline 17 & Nem Insurance Plc & $23(69.7 \%)$ & $\mathrm{E}$ & $10(30.3 \%)$ & $\mathrm{C}$ \\
\hline 18 & Niger Insurance Plc & $45(95.7 \%)$ & $\mathrm{E}$ & $2(4.3 \%)$ & $\mathrm{B}$ \\
\hline 19 & Prestige Assurance Plc & $46(100 \%)$ & $\mathrm{E}$ & $0(0 \%)$ & $\mathrm{A}$ \\
\hline 20 & Regency Alliance Insurance Plc & $41(89.1 \%)$ & $\mathrm{E}$ & $5(10.9 \%)$ & $\mathrm{C}$ \\
\hline 21 & Royal Exchange Plc & $44(91.7 \%)$ & $\mathrm{E}$ & $4(8.3 \%)$ & $\mathrm{B}$ \\
\hline 22 & Sovereign Trust Insurance Plc & $45(83.3 \%)$ & $\mathrm{E}$ & $9(16.7 \%)$ & $\mathrm{B}$ \\
\hline 23 & Staco Insurance Plc & $40(97.6 \%)$ & $\mathrm{E}$ & $1(2.4 \%)$ & $\mathrm{B}$ \\
\hline 24 & Standard Alliance Plc & $33(86.8 \%)$ & $\mathrm{E}$ & $5(13.2 \%)$ & $\mathrm{C}$ \\
\hline 25 & Unic Insurance Plc & $17(94.4 \%)$ & $\mathrm{E}$ & $1(5.6 \%)$ & $\mathrm{B}$ \\
\hline 26 & Unity kapital Assurance Plc & $46(88.5 \%)$ & $\mathrm{E}$ & $6(11.5 \%)$ & $\mathrm{C}$ \\
\hline 27 & Universal Plc & $22(73.3 \%)$ & $\mathrm{E}$ & $8(26.7 \%)$ & $\mathrm{C}$ \\
\hline 28 & Wapic Insurance Plc & $46(76.7 \%)$ & $\mathrm{E}$ & $14(23.3 \%)$ & $\mathrm{C}$ \\
\hline
\end{tabular}

Source: Computed By the Researcher (2019)

The analysis of the gender composition in the board of the sampled insurance companies gleaned from the above table 5 is quite revealing and intriguing. It is observed that the male directors are adequately represented and of higher proportions compared with the female directors across the sampled insurance companies in the period under reference. The male directors in terms of number dominate and outweigh the female counterparts. By categorization, it shows that only one company, Prestige Assurance PLC, out of the twenty eight sampled insurance companies had no women represented in the board. Eleven of the listed insurance firms on the average in the reference period had female directors marginally represented on the board. The firms are Aiico Insurance PLC, Guinea Insurance PLC, and Mutual Benefits Assurance PLC, Cornerstone Insurance PLC, Custodian \& Allied Insurance PLC, Gold Link Insurance PLC, Linkage Assurance PLC, Niger Insurance PLC, Royal Exchange Insurance PLC, Staco Insurance PLC and Unic Insurance PLC. These identified firms had less than and/or exactly ten percent of female director composition in the board. The smallness female director composition across the selected insurance firms could be adduced to high discrimination and power drunk mentality of the male counterparts. This has often snowballed into board room squabble and politics as well as conflict of interest in decision making by the directors particularly in the Nigerian perspective. Thirteen (13) of the listed insurance firms were observed to have less than thirty percent female director composition in the board. This in terms of categorization is a fair representation. These insurance companies encompass African Alliance insurance PLC, Axa mansard Insurance PLC, Consolidated Hall mark PLC, Equity Assurance PLC, Great Insurance PLC, International Energy Insurance PLC, Nem insurance PLC, Regency Alliance insurance PLC, Sovereign Trust insurance PLC, Standard Alliance insurance PLC, Unity capital Assurance 
PLC, Universal insurance PLC and Wapic Insurance PLC. Only two (2) of the insurance firms (Law union., Rock insurance PLC., \& Lasaco Assurance PLC) had female director averagely represented on the board. The empirical analysis does affirms the suggestions of researchers and the general public on the need to timely legislate for women inclusion on the corporate board of listed firms through effective policy backed by strict regulation and disclosure in Nigeria. This will enable the country to gradually join the league of nation that has quota of women directors well represented on the board of the firms for overall benefits purpose.

Table 6: Correlation Matrix

\begin{tabular}{|c|c|c|c|c|c|}
\hline & ETR2 & BSIZE & BLAU & BIND & SIZE \\
\hline ETR2 & 1 & & & & \\
\hline BSIZE & -0.017 & 1 & & & \\
\hline BLAU & -0.053 & 0.051 & 1 & & \\
\hline BIND & 0.155 & 0.116 & -0.246 & 1 & 0.000 \\
\hline SIZE & -0.014 & 0.219 & 0.003 & 0 & 1 \\
\hline
\end{tabular}

Source: Researcher's Computation from 2019 from E-Views 8.0 Version

The above table 6 shows the Pearson Correlation Coefficients of effective tax rate (ETR) and corporate governance mechanisms. Table 6 result shows that board size and ETR are negatively associated with effective rate (tax aggressiveness) $(r=-0.017)$. This suggests that the size of the board in the insurance firms contributed to the reduction of tax expense. Board of directors, especially a relatively large sized type and managers' interest may not align with those of the shareholders except they are adequately incentivized with a view to reduce the possibility of agency problem. The finding is related to Ribeiro (2015). BLAU and ETR is negatively associated ( $r=-0.053)$. It is an indication that board gender is not strong enough to positively influence tax aggressiveness of insurance firms in Nigeria. Board independence (BIND) and ETR are positively associated $(r=0.155)$ towards influencing effective tax rate. SIZE and ETR is negatively correlated $(\mathrm{r}=-0.014)$. Board size (BSIZE) is positively correlated with BIND ( $\mathrm{r}=$ $0.051, r=-0.116)$. While BSIZE is positive with gender diversity $(r=0.051)$. BLAU is strong and positively associated with BIND and SIZE $(r=0.246, r=0.003)$; BIND is weak and positively correlated with SIZE $(r=0.000)$. The associations do not in any way show signs of multicollinearity among the variables in the model. It is a pointer that the corporate governance mechanisms are mutually reinforcing at influencing tax aggressiveness.

Table 7: Panel Generalized Method of Moment Regression Result(Dependent variable: ETR2)

\begin{tabular}{|l|l|l|}
\hline \multicolumn{1}{|c|}{ Variables } & \multicolumn{1}{|c|}{ Coefficient } & \multicolumn{1}{|c|}{ Prob.value } \\
\hline ETR2(-1) & $0.860 * * * * * * 1$ & \\
\hline & $(1.928)$ & 0.656 \\
\hline BSIZE & {$[0.446]$} & \\
\hline & $173.022 * * * * *$ & \\
\hline BLAU & $(163.064)$ & 0.002 \\
\hline & {$[-1.061]$} & \\
\hline & $26.262 * * * * *$ & \\
\hline BIND & $(3212.428)$ & 0.093 \\
\hline & {$[0.008]$} & \\
\hline & $28.429 * * * * *$ & \\
\hline SIZE & $(30.278)$ & 0.050 \\
\hline & {$[0.938]$} & \\
\hline & $-1916.384 * * * * *$ & \\
\hline J-statistic=0.854 & $(2237.747)$ & 0.394 \\
\hline Instrumental Rank=6 & {$[-0.856]$} & \\
\hline Mean dependent Var $=4.330$ & & \\
\hline S.E. of regression= 555.826 & & \\
\hline S.D dependent var= 182.7913 & & \\
\hline
\end{tabular}

$* * * * * *$ Coefficient values, ( ) *standard error in bracket and [ ] $*$ T-statistic value in parenthesis

Source: Researcher's Computation 2019 from E-view 8.0 version

From table 7, it can be observed that the Hansen J- statistic of over-identifying restrictions has a value of 0.854 ; and this accepts the null hypothesis that the variables were uncorrelated with the error term in the model. The coefficient 
of the individual explanatory variables shows that board size (BSIZE) is positively signed (173.022) against tax aggressiveness and is statistically significant at 5\% level. BLAU is positively signed (26.262) against tax aggressiveness and is statistically significant at 9\% level. BIND is positively signed (28.429) against tax aggressiveness and is statistically significant at 5\% level. SIZE is negatively signed (-1916.384) against tax aggressiveness and is statistically not significant at 5\% level. The finding obtained showed that board size is negative and exerts significant impact on tax aggressiveness. Literarily, the finding is somewhat with the postulation of Jensen (1993) that the impact of the board depends on its size. The result obtained in this regard is not surprising! For instance, the average board size of the sampled firms in this study is 9. Albeit, the negative effect may not unconnected with smallness of sampled size and period used. The finding is in line with Minnick and Noga (2010); Lanis and Richardson (2007), Vafeas (2010); Mahenthiran and Kasipilai (2012) who found that small board size is significant and negatively impact on tax aggressiveness. Particularly, Minnick and Noga (2010) reported that the small board of directors strengthens the good tax management while large boards do prove ineffective because of the difficulties in decision - making about tax aggressiveness policy. Boussaidi and Hamed (2015) in their finding reported that the smaller corporate board is likely to increase the decision - making and regulatory compliance and thereby reduces the amount of tax aggressiveness. The finding of this study does not agree with the findings of prior researchers like Aliani and Zarai (2012); Koanantachai (2013); Zemzam and Flouhi (2013) who found an insignificant and positive relationship between board size and tax aggressiveness. Female director was found to be not significant and positively related with tax aggressiveness of firms in Nigeria. This affirms the women risk aversion theory. The finding failed to agree with that of Adams and Funk (2012); Boussaidi and Hamed (2015), Chen et al. (2010). The finding is however in tandem with studies like Aliani and Zarai (2012); Oyeleke et al. (2016) who reported positive and non- significant relationship between board gender and tax aggressiveness. The non significant effect of board gender on tax aggressiveness may not be unconnected with the marginalization of women on the corporate board in Nigeria. In Nigeria for example, there appears to be high level of politics and biasness on the corporate board. The selection and composition of board members is conspicuously skewed in favour of the male folks. Yes, there are women who have the requisite experience, managerial prowess, emotional strength and political clout to turn the wheel of progress in the right direction in quoted firms. Yet they are not considered for appointment into the corporate board, let alone putting them on significant position in the company board. Most unfortunate enough is the fact that they are even seen as a set of human creatures, whose duties should be to attend to the domestic needs of the family. This is never the less of the fact that women are more diligent in the attendance of board meeting than the male counter parts and more likely to join committee that monitor performance, inclusive of the level of tax aggressiveness. Board independence is significant and exerts a positive influence on tax aggressiveness of insurance firms in Nigeria. The finding of this study agrees with Yeung (2010) position that increase in board independence decrease tax expenses. Albeit, the influence of board independence at minimizing tax expense is made possible if they are vast in tax management. The finding is also in consonance with Lanis and Richardson (2007) and Aliani (2013). This study finding fails to agree with other studies like Zemzem and Flouhi (2013) and Ying (2011), which establish that board independence has a positive and no significant effect on tax aggressiveness. Firm size was found to positively influence effective tax rates. It is an indicator with a high prediction power over ETRs. However, the direction of the relationship between firm size and ETRs could be ambiguous. The study is not in tandem with other studies like Ribeiro (2015), Kraft (2014) and Rego (2003) which established a positive and non- significant relationship between firm size and tax aggressiveness. It is however contrary with studies like Dyreng et al. (2008), Stickney and McGree (1982), Boussaidi and Hamed (2015) which found a negative and non significant relationship between firm size and tax aggressiveness. Naturally, larger companies with track record of success history appear to be exposed to better political scrutiny which tends to reduce the chances of tax aggressiveness. Similarly, firm with huge investment in physical assets for example tend to use higher value of depreciation expense to reduce their assessable income and therefore play lower income tax expense.

\section{Conclusion and Recommendations}

This study has investigated how female director contributes to minimization of tax liability of listed insurance firms in Nigeria. The research showed that female director contributes to tax aggressiveness of listed insurance companies in Nigeria. Board size and board independence showed positive and significant relationship with tax aggressiveness of the insurance firms. Similarly, the result revealed that insurance firms are highly tax aggressive. This study concludes that female directors are highly underrepresented on the corporate board of listed insurance firms in Nigeria. The study recommends that corporate organizations whose board consists of eight members should have at 
least a minimum of three females to enable them optimize the benefits of female inclusivity. This study suggests that the government of Nigeria through the instrumentality of the national Assembly legislate for female inclusion on corporate board in companies and also make it mandatory for those firms to engage in full disclosure of the proportion of female on the corporate board in compliance with the approved legislation. This should enable Nigeria to join the league of those countries that have embraced a defined quota of females on the corporate board in Nigeria.

\section{Reference}

Adams, R.B., \& Funk, P.C. (2012). Beyond the glass ceiling: Does gender matter?. Management Science, 58(2), 219- 235 .

Aliani, K. (2013). Does corporate governance affect tax planning? Evidence from American companies. International Journal of Advanced Research, 1(10), 864 - 873.

Aliani, K., \& Zarai, A. (2012). Demographic diversity in the board and corporate tax planning in American firms. Business Management and Strategy, 3(1), 72-86.

Bernoulli, D. (1954). Exposition of a new theory on the measurement of risk. Econometrica, 22(1), 23-36.

Blau, P.M. (1977). Inequality and heterogeneity. New York, NY: Free press.

Boussaidi, A., \& Hamed, M. S. (2015). The impact of governance mechanisms on tax Aggressiveness: Empirical evidence from Tunisian context. Journal of Asian Business Strategy, 5(1), 1-12.

Chen, S., Chen, X., Cheng, Q., \& Shevlin, T. (2010). Are family firms more tax aggressive than non-family firms?. Journal of Financial Economics, 95(1), 41-61.

Dyreng, S., Hanlon, M., \& Maydew, E. (2010). The effects of executives on corporate tax avoidance. The Accounting Review, 85(4), 1163-1189.

Hausman , J.A. (1978). Specification Tests in Econometrics. Econotmtrica, 46(6), 1251-1271.

Jensen, M.C. (1993). The modern industrial revolution, exit, and the failure of internal control systems. Journal of Finance, 48, 831-880.

Kahneman, D., \& Tversky, A. (1979). Prospect theory: An analysis of decision under risk. Econometrica, 47(2), 263-291.

Koanantachai, R. (2013). Tax aggressiveness, corporate governance and firm value: an evidence from Thailand, being a published master of science in financial, submitted to faculty of commerce and accountancy, Thaminaat University, Bangkok, Thailand.

Kraft, A. (2014). "What really affects German firms' effective tax rate?". International Journal of Financial Research, 5(3), 1-19.

Lanis, R., \& Richardson, G.(2007). Board of director gender and corporate tax aggressiveness: an empirical analysis. Journal of Business Ethics, 144, 577-596. DOI:10.1007/s10551-015-2815-x, 1-20.

Minnick, K., \& Noga, T. (2010). Do corporate governance characteristics influence tax management?. Journal of Corporate Finance, 16, 703-718. http://dx.doi.0rg/10.1016 /j.jcorpfm.2010.08.005. 
Oyeleke, O.E.O., Erin. O., \& Emeni, F. (2016). Female directors and tax aggressiveness of listed banks in Nigeria. $3^{\text {rd }}$ International conference on African development issues covenant university press, $293-299$.

Stickney, C., \& McGee, V. (1982). Effective corporate tax rates: The effect of size, capital intensity, leverage, and other factors. Journal of Accounting and Public Pol-icy, 25(5), 574-595.

Von Neumann, J., \& Morgenstern, O. (1944). Theory of Games and Economic Behavior. Princeton: Princeton Univ Press.

Yeung, C.T. (2010). Effects of corporate governance on tax aggressiveness. An honours degree project, Hong Kong Baptist University.

Zemzem, A., \& K. Flouhi (2013). The effects of board of directors' characteristics on tax aggressiveness. Research Journal of Finance and Accounting, 4(4), 140-147. 